
published four times annually in cooperation with Transaction Periodicals Consortium by the University of Miami North-South Center for the Institute of Interamerican Studies, P.O. Box 248205, Coral Gables, FL 33124-3027. Copyright 1994 (ISSN 0022-1937) by the University of Miami, Institute of Interamerican Studies. All rights reserved. No portion of the contents may be reproduced in any form without written permission of the publisher.

Authorization to photocopy items for internal or personal use, or the internal or personal use of specific clients, is granted by the University of Miami, Institute of Interamerican Studies, for libraries and other users registered with the Copyright Clearance Center (CCC) Transactional Reporting Service, providing that the base fee of 25 cents per copy, plus 10 cents per copy page, is paid directly to CCC, 21 Congress St., Salem, MA 01970 . This consent does not extend to other kinds of copying, such as for general distribution, for advertising or promotional purposes, for creating new collective works, or for resale.

The JOURNAL is abstracted or indexed in Hispanic American Periodicals Index, Historical Abstracts, International Political Science Abstracts, Public Affairs Information Service, Current Contents, Social Sciences Citation Index, Social Sciences Index, ABC POL SCI, and United States Political Science Documents; it also is available on $16 \mathrm{~mm}$ microfilm, $35 \mathrm{~mm}$ microfilm, and $105 \mathrm{~mm}$ microfiche from University Microfilms, Inc., Ann Arbor, Michigan.

SUBSCRIPTIONS: Per year institutional rate will be $\$ 80.00$; individuals, $\$ 42.00$; continental US students only (with proof of current registration), $\$ 20.00$. Application to Mail at Second Class Postage Rates is pending at Coral Gables, FL, U.S.A.. Rates for international subscribers are $\$ 104.00$ for institutions, $\$ 68.00$ for individuals. All European and Israeli orders should be sent to Swets Publishing Service, Heereweg 347, 2161 CA, Lisse, The Netherlands.

BACK ISSUES, business communications, permissions, subscriptions orders, and change-of-address requests (send old label or address along with your new address) are to be sent to Journal of Interamerican Studies and World Affairs, Dept. 4010, Transaction Periodicals Consortium, Rutgers University, New Brunswick, NJ 08903.

ADVERTISING RATES and information are available from the advertising director at the above Transaction Periodicals Consortium address (telephone:908-932-2280); all copy is subject to publisher's approval.

CLAIMS for undelivered copies must be made no later than three months following the date of publication. If loss occurs in transit, the publisher will replace missing copies as reserve stocks permit. 
EDITORIAL CORRESPONDENCE: Address all correspondence and permission requests to the Journal of Interamerican Studies and World Affairs, University of Miami, P.O. Box 248205, Coral Gables, FL 33124-3027, U.S.A..

\section{ATTENTION AUTHORS}

The Journal of Interamerican Studies and World Affairs publishes articles that deal primarily with contemporary USLatin American relations, US foreign policy regarding Latin America, Latin American nations' relations with each other and the rest of the world, and Latin American internal affairs when such have clear implications for US foreign policy. The editors also welcome from scholars and public figures worldwide articles about political, economic, cultural, and social aspects of Latin American Interrelationships.

This is a refereed journal. All submissions are sent to qualified reviewers to determine acceptance for publication.

Send manuscripts in duplicate to address below, typewritten and double spaced. Place footnotes, references, tables, and charts on separate pages following current Journal style.

Upon acceptance, you will be asked to provide all tables and charts accompanying the manuscript on computer disks (either IBM-compatible or Macintosh) in addition to two complete, double-spaced printouts of disk material. Tables, charts, maps or other graphic materials will not be used unless provided on computer disks and in a file that is separate from that of the text. Columns in tables and charts should use tabs instead of individual spacing. A brief biographical sketch of the author should accompany the final manuscript.

Correspondence regarding book reviews should be directed to the Book Review Editor at the Journal of Interamerican Studies and World Affairs, University of Miami, P.O. Box 284205, Coral Gables, FL, 33124-3027. 


\title{
NorthיSouth Center
}

U N I V E R S I T Y O O F M I A M I

\section{Security, Democracy, and Development in U.S.-Latin American Relations}

\author{
Lars Schoultz, William C. Smith, \\ and Augusto Varas, editors \\ (304 pp; ISBN 1-56000-760-5; 1994) \$22.95
}

The very concept of "Latin America" is undergoing a redefinition,
as the economies of the United States, Canada, Mexico, and some of the Caribbean Basin nations are becoming integrated into a wider North American economic system. This "post-Latin America" might well be characterized by several subregional systems, with sharply differing economic, political, and strategic potentials and levels of influence in the emerging world system.

Nowhere is the situation more fluid, and nowhere are the possibilities for constructive change more promising than in the balancing of security, democracy, and development needs in the region. Leading experts on inter-

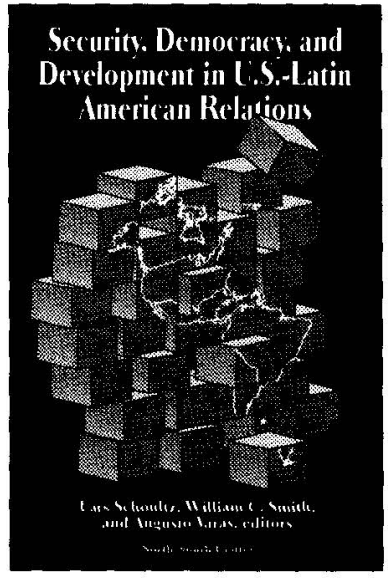
American security issues from the United States and Latin America explore the impact of global changes on the Western Hemisphere.

\section{University of Miami North-South Center Books \\ 7 Distributed by Transaction Publishers, Rutgers University \\ 16 New Brunswick, New Jersey $08903 /$ (908) 445-2280}

